\title{
An Econometric Analysis of the Determinants of Private Consumption in Cote d'Ivoire
}

\author{
Yaya Keho \\ Ecole Nationale Supérieure de Statistique et d'Economie Appliquée (ENSEA), Abidjan, Cote d'Ivoire \\ Email: yayakeho@yahoo.fr
}

How to cite this paper: Keho, Y. (2019) An Econometric Analysis of the Determinants of Private Consumption in Cote d'Ivoire. Theoretical Economics Letters, 9, 947-958.

https://doi.org/10.4236/tel.2019.94061

Received: December 6, 2018

Accepted: April 16, 2019

Published: April 19, 2019

Copyright ( 2019 by author(s) and Scientific Research Publishing Inc. This work is licensed under the Creative Commons Attribution International License (CC BY 4.0).

http://creativecommons.org/licenses/by/4.0/

(c) (i) Open Access

\begin{abstract}
This study investigates the determinants of private consumption expenditure in Cote d'Ivoire using time series data from 1970 to 2016. The Autoregressive Distributed Lags bounds testing approach to cointegration is employed to depict the presence of a long run relationship between private consumption and its determinants and an error correction model is estimated to derive short run dynamics. The results show the presence of a long run relationship among the selected variables. In the long run, current income, wealth and government consumption expenditure play a positive role in determining private consumption, with the effect of current income being higher. Furthermore, consumption expenditure is negatively affected by inflation rate and real interest rate on deposits. In the short run, only income and wealth appear to have positive effects on private consumption while the effects of government consumption, inflation and interest rate were found to be insignificant. This study provides evidence for government to improve the level of private consumption.
\end{abstract}

\section{Keywords}

Private Consumption, Gross Domestic Product, ARDL, Cote d'Ivoire

\section{Introduction}

Household consumption expenditure plays a crucial role in determining the welfare of populations and the dynamic effects of economic shocks. In most countries, it constitutes the largest component of gross domestic product. For instance, in Cote d'Ivoire, the share of household final consumption spending in GDP increased from $57.3 \%$ in 1970 to $63.5 \%$ in 1983 and reached a pic of $73.4 \%$ in 1992 [1]. It averaged around 68\% over the period 2000-2016. This makes private consumption in Cote d'Ivoire an extremely important component of aggre- 
gate demand and economic growth. What are the driving factors of private consumption in Cote d'Ivoire? Understanding the driving factors of household consumption is important because of its implications on saving, investment, economic growth, employment and human development. A better understanding of these factors would provide valuable information which can be used to guide economic growth and poverty-reducing policies.

As a result, the study on determinants of consumption expenditure has been an area of intensive research since Keynes [2] developed his model of consumption theory. According to the Keynes Absolute Income Hypothesis (AIH), current income is the main determinant of current consumption expenditure and as income increases consumption expenditure also increases but less than proportionately. This implies that the marginal propensity to consume is smaller than the average propensity to consume. However, this theory gives a static explanation of the consumption function since it does not consider individuals expected path of income or time preference for consumption. [3] utilized time series data and found that consumption functions had an insignificant intercept term, implying that average and marginal propensities to consume were the same. This empirical puzzle opened up the opportunity to extend the literature on consumption function. [4] challenged the Keynesian theory of consumption and introduced the Relative Income Hypothesis. According to this hypothesis household consumption depends not just on its current income, but on its income relative to those of its group. Conversely, the Life Cycle Hypothesis due to [5] and [6], stipulates that household consumption depends in part on current income, but also on lifetime expected income and wealth. In other words, households consider their entire life span when making consumption decisions. Similarly, the Permanent Income Hypothesis (PIH) advocated by [7] showed that consumption is determined by permanent income rather than transitory or relative income. Thus, this theory divides the current income into two parts: permanent income and transitory income. Permanent income represents the stable income which households expect to persist into the future while transitory income represents the difference between the short term current income and the permanent income. According to the Permanent Income Hypothesis, only changes in permanent income can alter consumption. This view explains why income is more volatile than consumption and why marginal propensity to consume is higher in long run than in short run. [8] introduced rational expectations into the life cycle and permanent income hypotheses and showed that consumption is a random walk. This implies that unexpected changes in permanent income can affect current consumption. The permanent income hypothesis provides the rational that private consumption responds to changes in permanent income, including asset wealth and human wealth. The introduction of wealth or permanent income into the analysis weakens the relationship between current income and current consumption. One of the key assumptions of these theories is that there exists a perfect financial market in which households can borrow or 
lend to smooth their consumption. However, in many developing countries, households have limited access to credit. As a consequence of being financially constrained, they rely more on their current income rather than their permanent income.

Based on these theories, a growing body of empirical studies have been undertaken to estimate consumption functions for many individual countries and groups of countries around the world. Most of these works examined the effect of one factor such as income or interest rate in a bivariate framework, ignoring the effects of other relevant factors such as government expenditure, inflation and financial depth. For instance, [9] rejected the PIH in Greece due to presence of liquidity constraints. [10] reported that income has a positive effect on private consumption while interest rate exerts a negative effect in Saudi Arabia. The effect of financial wealth was insignificant. [11] confirmed the positive role of income and broad money supply used as a proxy for wealth in determining private consumption in Saudi Arabia. [12] obtained evidence supporting the absolute income hypothesis rather than PIH in Pakistan due to existence of liquidity constraints. According to [13], private consumption in Iran is positively related to GDP and negatively associated with inflation. [14] rejected the PIH in favor of the AIH for China. Recently, some studies estimated determinants of private consumption by incorporating many explanatory variables into the analysis. In the African context, the empirical evidence is mixed and conflicting. For instance, [15] found no evidence of impact of growth of GDP on consumption expenditure in Tanzania. [16] confirmed the PIH in Ghana. In the case of Cameroon, [17] found that disposable income, price level, interest rate and dependency ratio impacted positively on private consumption. The results obtained by [18] suggested that an increase in income has no significant effect on private consumption in Nigeria. This finding has been challenged by [19] [20] [21] and [22] who reported a positive significant impact of income on private consumption. [23] examined the validity of the PIH for six African countries (Cameroon, Ghana, Kenya, Nigeria, Senegal and South Africa) and found this hypothesis holds in five out of the six countries. [24] and [25] also validated the absolute income hypothesis for Kenya. [26] showed that income and inflation have a long-run positive effect on household spending in Ghana. [27] investigated the case of Lesotho and found that higher income is associated with higher private consumption, while higher inflation and higher interest rates reduce private consumption. These findings contradict with [28] who found that private consumption is positively influenced by income and interest rates on deposits, while inflation has no effect on private consumption. Moreover, government expenditure was found to crowd out private consumption.

This review of the literature shows that studies on determinants of private consumption yield mixed results. A general consistency among the reviewed studies is the inclusion of income, inflation and interest rate as key drivers of private consumption. A general conclusion from this literature is that the impact 
of income on consumption is positive while that of inflation and interest rate is negative. However the role of government expenditure and wealth in explaining private consumption has not been widely explored. It is the intention of this study to fill the gap in the empirical literature. The paper investigates some key driving factors of private consumption expenditure in Cote d'Ivoire. The empirical framework applies the autoregressive distributed lag (ARDL) bounds testing approach to cointegration and error correction model to annual data covering the period from 1970 to 2016 .

The remainder of the paper is organized as follows. Section 2 outlines the econometric methodology employed for the empirical analysis. Section 3 reports the empirical findings of the study. Section 4 concludes the study and provides some policy recommendations.

\section{Econometric Model and Data}

\subsection{Model Specification}

The objective of this work is to estimate a relationship between private consumption expenditure and its macroeconomic determinants. Based on the empirical literature, the econometric model is built upon the following equation:

$$
\log C_{t}=\alpha+\beta_{1} \log Y_{t}+\beta_{2} \log W_{t}+\beta_{3} Z_{t}+\mu_{t}
$$

where $C_{t}$ is private consumption, $Y_{t}$ is income, $W_{t}$ stands for wealth, and $Z_{t}$ represents a set of other determinants which captures fiscal policy, liquidity constraints, substitution effects and macroeconomic uncertainty. In this study, $Z_{t}$ includes government consumption expenditure $\left(G_{t}\right)$, inflation rate $\left(I N F_{t}\right)$ and real interest rate $\left(r_{t}\right)$.

The impact of income and wealth on consumption expenditure is expected to be positive and smaller than one. The coefficient on government spending is ambiguous. Government expenditure can in some cases crowd in private consumption while in other cases it can crowd it out. The impact of inflation rate is negative because inflation lowers the real value of money balances and financial assets with fixed monetary values. The real interest rate reflects the substitution effects in terms of preference for current or future consumption. A priori, an increase in interest rate induces people to reduce consumption expenditure and increase saving. This substitution effect tends to decrease household consumption expenditure. On the other hand, higher interest rates increase the financial wealth of positive savers which in turn increases their consumption expenditure. Thus, the effect of interest rate is positive when the income effect dominates the substitution effect. The two effects may cancel each other leaving the total effect to be insignificant.

\subsection{Econometric Methodology}

We begin our empirical investigation by examining the time series properties of all variables. This step is necessary to make sure that we do not run spurious regressions. To this end, we apply the unit root tests of [29] and [30]. The second 
step depicts the presence of a long-run relationship among the variables. Econometric literature provides many techniques to investigate cointegration among macroeconomic variables. In this study, we employ the autoregressive distributed lag (ARDL) approach developed by [31]. One of the reasons for using the ARDL technique is that it is applicable irrespective of whether the regressors are stationary at level or stationary at first difference. It also performs better for small sample sizes than other cointegration techniques. It allows variables to have different optimal lags. The ARDL approach is based on the following error-correction model:

$$
\begin{aligned}
\Delta \log C_{t}= & \theta_{0}+\theta_{1} \log C_{t-1}+\theta_{2} \log Y_{t-1}+\theta_{3} \log W_{t-1}+\theta_{4} Z_{t-1}+\sum_{i=1}^{m 1} \gamma_{1 i} \Delta \log C_{t-i} \\
& +\sum_{i=0}^{m 2} \gamma_{2 i} \Delta \log Y_{t-i}+\sum_{i=0}^{m 3} \gamma_{3 i} \Delta \log W_{t-i}+\sum_{i=0}^{m 4} \gamma_{4} \Delta Z_{t-i}+\mu_{t}
\end{aligned}
$$

where $Z_{t}=\left(\log G_{t}, I N F_{t}, r_{t}\right)$.

The presence of long-run relationship among the variables is tested using the F-test statistic with the null hypothesis of no long-run relationship being $\mathrm{H}_{0}$ : $\theta_{1}=\theta_{2}=\theta_{3}=\theta_{4}=0$. The optimal lag structure $(m 1, m 2, m 3, m 4)$ was selected using the Akaike Information Criterion (AIC) with maximum lag length on each variable set to five. The model has been tested by the diagnostic tests that are serial correlation, normality and heteroskedasticity tests. Stability tests have also been used to test the goodness of fit of the model. The computed F-statistic has to be compared with two critical values bounds generated by [31]. If F-statistic is smaller than lower bound, then there is no long run cointegration relationship among the variables. If F-statistic is greater than upper bound, then there is long-term relationship among the variables. If F-statistic is between lower and upper bounds, then the results are inconclusive and different method is required.

\subsection{Data}

The study uses annual data covering the period 1970-2016. Variables used include private consumption measured as household real final consumption expenditure $\left(C_{t}\right)$, real GDP used as a proxy for income $\left(G D P_{t}\right)$, real financial wealth $\left(W_{t}\right)$, real government final consumption expenditure $\left(G_{t}\right)$, inflation rate $\left(I N F_{t}\right)$ measured by the log difference of consumer price index, and real interest rates on deposits $\left(r_{t}\right)$ calculated as the difference between nominal interest rate and inflation rate. Given the lack of suitable data for wealth, monetary aggregates are often used to represent financial wealth (see, [10] [11] [32] [33] [34]). In this study, real broad money M2 was used as a proxy for financial wealth. Real values for wealth were obtained by deflating nominal values with the consumer price index. All data series were obtained from the World Development Indicators of the World Bank [1]. All series except inflation rate and interest rate were converted into natural logarithms so that they can be interpreted in growth terms after taking first difference and their respective coefficients represent elasticities. 
Table 1 shows descriptive statistics and correlations of the variables. The log of real household consumption averaged 29.404 over the sample period, and ranged from 28.676 to 30.158 with a standard deviation of 0.309 . The average of $\log$ of real GDP is 29.828 with a standard deviation of 0.278 . Thus, about $67 \%$ of Ivorian's GDP goes to household consumption. The correlation matrix indicates positive relationships between private consumption and its determinants, except inflation rate which shows a negative correlation coefficient.

\section{Empirical Results and Discussion}

As indicated in the methodology, we begin our empirical analysis by examining the time-series properties of the variables. The results displayed in Table 2 show that inflation rate (INF) and real interest rate (r) are stationary at level while the rest of the variables are stationary at first-difference. This shows that variables under study have different orders of integration. In such context, the ARDL bounds testing approach is suitable to examine the long run relationship among the variables.

The results of the ARDL bounds test are reported in Table 3. The computed F-statistic exceeds the upper critical value at $5 \%$ level of significance, suggesting that a long run relationship exists between private consumption and its determinants. At

Table 1. Descriptive statistics and correlation matrix.

\begin{tabular}{|c|c|c|c|c|c|c|}
\hline Variables & $\log C$ & $\log \mathrm{GDP}$ & $\log W$ & $\log G$ & INF & $\mathrm{r}$ \\
\hline \multicolumn{7}{|c|}{ Panel A: Summary statistics } \\
\hline Mean & 29.404 & 29.828 & 28.556 & 27.916 & 6.100 & -1.392 \\
\hline Median & 29.338 & 29.774 & 28.456 & 27.968 & 4.020 & 0.422 \\
\hline Maximum & 30.158 & 30.481 & 29.583 & 28.427 & 27.421 & 7.805 \\
\hline Minimum & 28.676 & 29.167 & 27.907 & 27.237 & -0.805 & -22.581 \\
\hline Std. dev. & 0.309 & 0.278 & 0.359 & 0.231 & 6.451 & 6.205 \\
\hline Skewness & 0.057 & -0.124 & 1.078 & -0.433 & 1.613 & -1.684 \\
\hline Kurtosis & 3.182 & 3.263 & 4.047 & 3.840 & 5.414 & 6.142 \\
\hline Jarque-Bera & 0.090 & 0.258 & 11.261 & 2.855 & 31.815 & 41.568 \\
\hline Probability & 0.955 & 0.878 & 0.003 & 0.239 & 0.000 & 0.000 \\
\hline \multicolumn{7}{|c|}{ Panel B: Correlation matrix } \\
\hline $\log C$ & 1.000 & & & & & \\
\hline $\log G D P$ & $0.985^{*}$ & 1.000 & & & & \\
\hline $\log W$ & $0.800^{*}$ & $0.774^{*}$ & 1.000 & & & \\
\hline $\log G$ & $0.819^{*}$ & $0.802^{*}$ & $0.759^{*}$ & 1.000 & & \\
\hline INF & $-0.392^{\star}$ & $-0.368^{\star}$ & -0.134 & $-0.256^{\star *}$ & 1.000 & \\
\hline $\mathrm{r}$ & $0.309^{*}$ & $0.285^{\star \star}$ & 0.074 & $0.260^{\star *}$ & $-0.969^{*}$ & 1.000 \\
\hline
\end{tabular}

Note: $\mathrm{C}=$ Household real final consumption, GDP = real GDP, $\mathrm{W}=$ real M2, G = Government final consumption, INF = Inflation rate as log difference of consumer price index, $\mathrm{r}=$ real interest rate on deposits. The asterisks ${ }^{\star}$ and ${ }^{\star *}$ denote statistical significance at the $5 \%$ and $10 \%$ levels, respectively. 
Table 2. Results of unit root tests.

\begin{tabular}{cccccc}
\hline \multirow{2}{*}{ Series } & \multicolumn{2}{c}{ Level } & \multicolumn{2}{c}{ First difference } & Order of integration \\
\cline { 2 - 5 } & PP & KPSS & PP & KPSS & \\
\hline $\log \mathrm{C}$ & -2.144 & 0.093 & $-5.096^{*}$ & 0.157 & $\mathrm{I}(1)$ \\
$\log \mathrm{GDP}$ & -2.388 & 0.085 & $-4.273^{*}$ & 0.139 & $\mathrm{I}(1)$ \\
$\log \mathrm{W}$ & -0.321 & $0.506^{*}$ & $-6.013^{*}$ & 0.212 & $\mathrm{I}(1)$ \\
$\log$ & -2.934 & 0.099 & $-7.810^{*}$ & 0.161 & $\mathrm{I}(1)$ \\
$\mathrm{INF}$ & $-3.753^{*}$ & $0.504^{*}$ & $-9.046^{*}$ & 0.061 & $\mathrm{I}(0)$ \\
$\mathrm{r}$ & $-4.331^{*}$ & 0.055 & $-8.922^{\star}$ & 0.074 & $\mathrm{I}(0)$ \\
\hline
\end{tabular}

Note: $\mathrm{C}=$ Household real final consumption, GDP $=$ real GDP, $\mathrm{W}=$ real $\mathrm{M} 2, \mathrm{G}=$ Government real final consumption, INF = Inflation rate as log difference of consumer price index, $r=$ real interest rate on deposits. ${ }^{*}$ denotes the rejection of the null hypothesis at the $5 \%$ level.

Table 3. Results of the ARDL cointegration test.

\begin{tabular}{ccccc}
\hline \multirow{2}{*}{ Model } & F-stat. & \multicolumn{3}{c}{ Diagnostic tests } \\
\cline { 3 - 4 } & & Normality $^{1}$ & Heteroskedasticity $^{2}$ & Correlation $^{3}$ \\
\hline ARDL $(4,5,1,5,5,2)$ & $4.526^{*}$ & 0.790 & 0.296 & 0.298 \\
\hline Critical value & Lower bound value & Upper bound value \\
\hline $1 \%$ & 2.82 & 4.21 \\
$5 \%$ & 2.14 & 3.34 \\
$10 \%$ & 1.81 & 2.93 \\
\hline
\end{tabular}

Note: 1) $p$-value of Jarque-Bera test, 2) p-value of Breusch-Pagan-Godfrey test, 3) p-value of BreuschGodfrey Serial Correlation LM Test. Lag structure of the ARDL model was selected using the AIC criterion with maximum lag set to 5. Critical values of the F-test were obtained from Pesaran et al. [31] under the model with no intercept and trend. $\left({ }^{*}\right)$ indicates the rejection of the null hypothesis of no cointegration at $5 \%$ level of significance.

the 5\% significance level, all diagnostic tests do not exhibit any evidence of violation of the classical linear regression model assumptions. That is the error terms have a constant variance, and are independently and normally distributed.

Since the variables under study are cointegrated, we estimate the long run consumption function. To that end, we apply the ARDL approach along with the Fully Modified OLS method proposed by [35] and the Dynamic OLS technique suggested by [36]. The long run marginal effects are presented in Table 4 . The estimated coefficient on real GDP (proxy for total income) is highly significant and has the correct sign as expected. A $1 \%$ increase in income leads to about $0.6 \%$ increase in household consumption expenditure, all else is same. The wealth elasticity is about 0.10 and smaller than that of current income. Financial market is not very developed in Cote d'Ivoire and is mostly dominated by banks with the banking sector funds lending primarily to private corporate and state. The evidence of this study indicates that consumers in Cote d'Ivoire depend on current income for their current consumption. This provides support to the Keynesian absolute income hypothesis in Cote d'Ivoire. This finding is also consistent 
Table 4. Long run consumption function, 1970-2016.

\begin{tabular}{ccccccc}
\hline \multirow{2}{*}{ Regressor } & \multicolumn{4}{c}{ Dependent variable: log of private consumption $(\log C)$} \\
\cline { 2 - 7 } & \multicolumn{2}{c}{ ARDL } & \multicolumn{2}{c}{ FMOLS } & \multicolumn{2}{c}{ DOLS } \\
\cline { 2 - 7 } & Coef. & t-stat. & Coef. & t-stat. & Coef. & t-stat. \\
\hline Income & $0.618^{*}$ & 10.923 & $0.867^{*}$ & 11.030 & $0.317^{*}$ & 2.024 \\
Wealth & $0.106^{*}$ & 3.859 & 0.061 & 1.460 & $0.111^{* *}$ & 1.697 \\
Gov. consumption & $0.290^{*}$ & 4.259 & $0.167^{*}$ & 2.310 & $0.413^{*}$ & 6.857 \\
Inflation & $-0.035^{*}$ & -8.458 & $-0.013^{* *}$ & -1.660 & $-0.081^{*}$ & -4.137 \\
Interest rate & $-0.026^{*}$ & -5.647 & -0.009 & -1.361 & $-0.067^{*}$ & -3.848 \\
\hline
\end{tabular}

Note: The asterisks ${ }^{*}$ and ${ }^{*}$ denote statistical significance at the $5 \%$ and $10 \%$ levels, respectively.

with other studies ([17] [20] [21] [24] [25] [26] [27] [37]), but contradicts with [18] and [19] who found no significant effect of gross domestic product on private consumption expenditure.

The coefficient on government consumption is about 0.3 and significant, implying that an increase of $1 \%$ in government final consumption causes household consumption expenditure to rise by $0.3 \%$. This evidence strongly indicates that government expenditure has a complementary relationship with private consumption. Therefore, government expenditure can be used to induce household consumption growth. This finding supports the Keynesian effects of fiscal policy on private consumption.

The impact of inflation on household consumption is negative and significant, implying that increases in the level of inflation lessen the level of goods and services demanded by households. This finding lends support to the real balance effect of inflation. Finally, the effect of interest rate on consumption is negative and significant implying that higher interest rates on deposits reduce private consumption. This finding suggests that the substitution effect outweighs the income effect in respect of the choice between saving and consumption. Our findings for inflation and interest rate are in line with [27] who found that higher inflation and higher interest rates reduce private consumption.

We have estimated the error correction model to obtain short run dynamic relationship and results are reported in Table 5. The coefficient on the lagged error correction term is negative and statistically significant, supporting the existence of a long run relationship between private consumption and its determinants. The estimated short run elasticity of current consumption with respect to current income is 0.473 and is highly statistically significant at the $5 \%$ level. This means that a $1 \%$ increase in current income will result in a $0.478 \%$ rise in private consumption. However, the long run impact of income on private consumption is greater than in the short run. This could mean that households save more and consume less in the short run than in the long run as income grows. The coefficient on income is higher than those of the other variables both in the short and long run. This shows the strong relationship between current consumption and current income, as advocated by the Keynesian theory of consumption. The 
Table 5. Short run consumption function, 1970-2016.

\begin{tabular}{cccc}
\hline \multirow{2}{*}{ Regressor } & \multicolumn{3}{c}{ Dependent variable: Growth rate of private consumption } \\
\cline { 2 - 4 } & Coefficient & t-statistic & Prob. \\
\hline$\Delta$ Income & $0.473^{*}$ & 3.073 & 0.004 \\
$\Delta$ Wealth & $0.162^{*}$ & 2.805 & 0.008 \\
$\Delta$ Gov. consumption & 0.061 & 0.966 & 0.340 \\
$\Delta$ Inflation & -0.010 & -1.225 & 0.228 \\
$\Delta$ Interest rate & -0.005 & -0.807 & 0.425 \\
ECM $(-1)$ & $-0.424^{*}$ & -3.277 & 0.002 \\
\hline
\end{tabular}

Note: The short-run equation includes no constant. The asterisks * denotes statistical significance at the 5\% level.

strong effect of current income is consistent with how the economic system prevailed in Cote d'Ivoire and other African countries. Indeed, many African countries experience low liquidity options such as credit unavailability and low savings and most households are unable to use savings and borrowing to smooth their consumption. As a consequence of being financially constrained, they rely on current income.

The coefficients with respect to government consumption, inflation and interest rate were found not to be statistically significant in determining private consumption in the short run. For policy makers, this suggests that government expenditure cannot be used to stimulate private consumption in the short run.

\section{Conclusions and Recommendations}

The aim of this study was to investigate the determinants of private consumption expenditure in Côte d'Ivoire over the period from 1970 to 2016. Our empirical analysis employed the bounds test approach developed by [31]. The empirical findings indicate that income, wealth, government consumption, inflation and interest rate are key determinants of long run private consumption in Cote d'Ivoire. Furthermore, higher current income is associated with higher private consumption. This relationship is valid both in the short and long run and provides support to the Keynesian absolute income hypothesis in Cote d'Ivoire. The research findings also reveal that government consumption has a positive effect on household consumption while inflation and real interest rate on deposits exhibit negative effects. The negative effect of interest rate implies that the substitution effect dominates the income effect in the long run. Another implication of our results is that increases in deposits interest rates may be effective to stimulate domestic saving. The negative effect of inflation rate gives a signal to policy makers to control inflation to boost private consumption and reduce poverty among households.

The short run results show that household final consumption expenditure is mostly driven by income and wealth. The effects of inflation and real interest rate on deposits were found to be insignificant. Noteworthy, the effect of income 
on consumption in the short run was found to be less than it was in the long run. Moreover, private consumption has been found to be more sensitive to current income as indicated by a higher elasticity. Overall, the results reported in this study support the Keynesian theory of consumption. The excess sensitivity of consumption to current income indicates the existence of a robust incomeconsumption relation. In such a context, income tax reduction can have a considerable impact on household consumption expenditure. The positive relationship between government spending and private consumption also suggests that government spending can be used to stimulate aggregate demand and economic growth in Cote d'Ivoire in the long run. Also, lower interest rates and inflation are recommended to increase household consumption.

This study does not explain the reasons of the strong relationship between current consumption and current income. Do credits constraints or myopia explain this result? It is important to investigate the validity of these hypotheses to provide valuable policy recommendations to government. We intend to examine this issue in a future research.

\section{Conflicts of Interest}

The author declares no conflicts of interest regarding the publication of this paper.

\section{References}

[1] World Bank (2018) World Development Indicators.

[2] Keynes, J.M. (1936) The General Theory of Employment, Interest and Money. Palgrave Macmillan, London.

[3] Kuznets, S. (1946) National Product since 1869. National Bureau of Economic Research, New York.

[4] Duesenberry, J.S. (1949) Income, Saving, and the Theory of Consumer Behavior. Harvard University Press, Cambridge.

[5] Modigliani, F. and Brumberg, R.H. (1954) Utility Analysis and the Consumption Function: An Interpretation of Cross-Section Data. In: Kurhira, K.K. Ed., PostKeynesian Economics, Rutgers University Press, New Brunswick, 388-436.

[6] Ando, A. and Modigliani, F. (1963) The "Life Cycle" Hypothesis of Saving: Aggregate Implications and Tests. The American Economic Review, 53, 55-84.

[7] Friedman, M. (1957) A Theory of Consumption Function. Princeton University Press, Princeton, NJ.

[8] Hall, R.E. (1978) Stochastic Implications of the Life Cycle-Permanent Income Hypothesis: Theory and Evidence. Journal of Political Economy, 86, 971-987. https://doi.org/10.1086/260724

[9] Drakos, K. (2002) Myopia, Liquidity Constraints, and Aggregate Consumption: The Case of Greece. Journal of Economic Development, 27, 97-105.

[10] Ibrahim, M.A. (2014) The Private Consumption Function in Saudi Arabia. American Journal of Business Management, 3, 109-116.

[11] Algaeed, A.H. (2016) Money Supply as a Conduit of the Consumption in the Saudi Economy: A Co-Integration Approach. International Journal of Economics, Finance 
and Management Sciences, 4, 269-274. https://doi.org/10.11648/j.ijefm.20160405.16

[12] Khan, K. and Mohammed, N. (2011) Permanent Income Hypothesis, Myopia and Liquidity Constraints: A Case Study of Pakistan. Pakistan Journal of Social Sciences, 31, 299-307.

[13] Nikbin, B. and Panahi, S. (2016) Estimation of Private Consumption Function of Iran: Autoregressive Distributed Lag Approach to Co-Integration. International Journal of Economics and Financial Issues, 6, 653-659.

[14] Lunfang, D., Khan, K., Khan, I. and Khan, N.H. (2018) Testing the Empirical Validity of Permanent Income Hypothesis and Absolute Income Hypothesis for China. The Empirical Economics Letters, 17, 453-460.

[15] Kweka, C. and Morrissey, O. (1998) Impacts of Economic Growth on Consumption Expenditures. Tanzanian Economic Journal, 15, 1-34.

[16] Osei-Fosu, A.K., Butu, M.M. and Osei-Fosu, A.K. (2014) Does Ghanaian's Consumption Function Follow the Permanent Income Hypothesis? The Cagan's Adaptive Expectation Approach. Africa Development and Resources Research Institute Journal, 4, 133-148.

[17] Forgha, N.G. (2008) Econometric Models of Consumption and Savings Functions in Cameroon: An Error Correction Methodology. International Review of Business Research Papers, 4, 291-308.

[18] Chioma, N.J. (2009) Causal Relationship between Gross Domestic Product and Personal Consumption Expenditure of Nigeria. African Journal of Mathematics and Computer Science Research, 2, 179-183.

[19] Adedeji, A.O. and Adegboye, A.A. (2013) The Determinants of Private Consumption Spending in Nigeria. International Journal of Business and Economic Research, 1, 103-116.

[20] Akekere, J. and Yousuo, P.O.J. (2012) Empirical Analysis of Change in Income on Private Consumption Expenditure in Nigeria from 1981 to 2010. International Journal of Academic Research in Business and Social Sciences, 2, 188-197.

[21] Odionye, J.C., Ugwuebe, U.S. and Sylvester, N.O.I. (2015) The Effect of Financial Wealth on Private Consumption: Evidence from Nigeria. British Journal of Economics, Management \& Trade, 6, 300-307. https://doi.org/10.9734/BJEMT/2015/13289

[22] Ezeji, C.E. and Ajudua, E.I. (2015) Determinants of Aggregate Consumption Expenditure in Nigeria. Journal of Economics and Sustainable Development, 6, 164-169.

[23] Nwala, K. (2010) Does Permanent Income Hypothesis Hold for Some Selected African Countries? African Journal of Business and Economic Research, 5, 27-34.

[24] Ofwona, A.C. (2013) An Estimation of the Consumption Function for Kenya Using Keynes' Absolute Income Hypothesis for the Period 1992-2011. Journal of Emerging Trends in Economics and Management Sciences, 4, 103-105.

[25] Mwangi, I. and Atieno, R. (2018) Impact of Financial Inclusion on Consumption Expenditure in Kenya. International Journal of Economics and Finance, 10, 114-128. https://doi.org/10.5539/ijef.v10n5p114

[26] Bonsu, C.O. and Muzindutsi, P.-F. (2017) Macroeconomic Determinants of Household Consumption Expenditure in Ghana: A Multivariate Cointegration Approach. International Journal of Economics and Financial Issues, 7, 737-745.

[27] Sekantsi, L.P. (2016) Determinants of Real Private Consumption Expenditure in Lesotho. European Journal of Economics and Management, 3, 72-89. 
[28] Damane, M. (2018) Empirical Analysis of Private Consumption in Lesotho: An ARDL Bound Test Approach. Modern Economy, 9, 400-421. https://doi.org/10.4236/me.2018.93026

[29] Phillips, P.C.B. and Perron, P. (1988) Testing for a Unit Root in a Time Series Regression. Biometrika, 75, 335-346. https://doi.org/10.1093/biomet/75.2.335

[30] Kwiatkowski, D., Phillips, P.C.B., Schmidt, P. and Shin, Y. (1992) Testing the Null Hypothesis of Stationarity against the Alternative of a Unit Root: How Sure Are We That Economic Time Series Have a Unit Root? Journal of Econometrics, 54, 159-178. https://doi.org/10.1016/0304-4076(92)90104-Y

[31] Pesaran, H., Shin, Y. and Smith, R.J. (2001) Bounds Testing Approaches to the Analysis of Level Relationships. Journal of Applied Econometrics, 16, 289-326. https://doi.org/10.1002/jae.616

[32] Bredin, D. and Cuthbertson, K. (2002) Liquidity Effects and Precautionary Saving in the Czech Republic. Applied Financial Economics, 12, 405-413. https://doi.org/10.1080/09603100110090181

[33] Saad, W. (2011) An Econometric Study of the Private Consumption Function in Lebanon. International Research Journal of Finance and Economics, 61, 29-41.

[34] Kazmi, S.M.A. (2015) Real Private Consumption Expenditure Modeling: An Empirical Study on Pakistan. Journal of Economics and Sustainable Development, 6, 36-47.

[35] Phillips, P.C.B. and Hansen, B.E. (1990) Statistical Inference in Instrumental Variables Regression with I(1) Process. The Review of Economic Studies, 57, 99-125. https://doi.org/10.2307/2297545

[36] Stock, J. and Watson, M.W. (1993) A Simple Estimator of Cointegrating Vectors in Higher Order Integrated Systems. Econometrica, 61, 783-820. https://doi.org/10.2307/2951763

[37] Onodje, A.M. (2009) An Insight into the Behavior of Nigeria's Private Consumer Spending. Economic and Policy Review, 15, 8-15. 